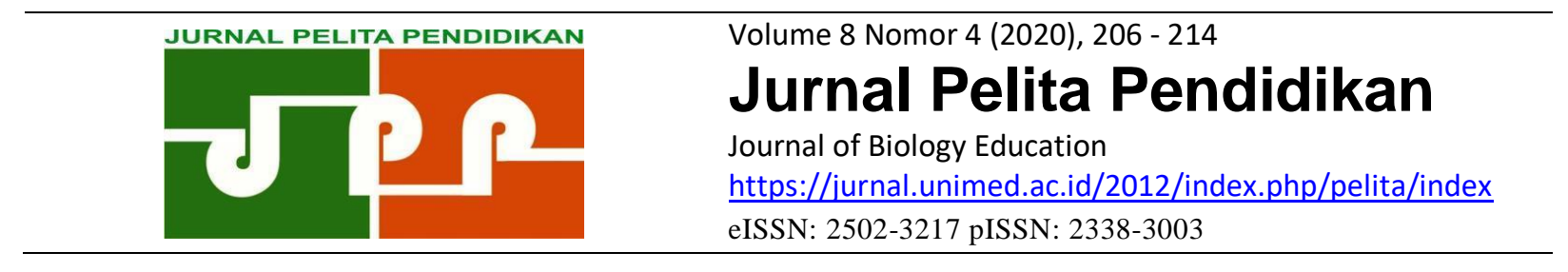

\title{
LEARNER AUTONOMY MAHASISWA PENDIDIKAN BIOLOGI PADA PEMBELAJARAN DARING SELAMA MASA PANDEMI
}

\author{
Rizqa Devi Anazifa*, Anggi Tias Pratama, Kintan Limiansi \\ Pendidikan Biologi, Fakultas Matematika dan Imlu Pengetahuan Alam, Universitas Negeri Yogyakarta \\ *Korespondensi Author: rizqa1992@uny.ac.id
}

\section{INFO ARTIKEL}

Riwayat artikel:

Diterima 27 November 2020

Revisi 3 Desember 2020

Dipublikasikan 28

Desember 2020

Kata kunci:

Learner autonomy, mahasiswa pendidikan biologi, pembelajaran daring

\begin{abstract}
ABSTRAK
Sebagai calon guru biologi, kemampuan untuk bertanggung jawab terhadap proses belajar sangat diperlukan untuk mengembangkan kemampuan mahasiswa untuk menguasai konsep-konsep Biologi dan keterampilan mengajar. Penelitian ini bertujuan untuk menginvestigasi kemandirian belajar mahasiswa Pendidikan Biologi selama mengikuti proses pembelajaran daring pada masa pandemi. Survei dilaksnakan pada 61 mahasiswa calon guru Biologi yang menempuh program Pendidikan Biologi dengan instrumen Autonomy Learning Scale (ALS) yang terdiri dari 12 pertanyaan. ALS mengukur dua aspek, yaitu kemandirian dalam belajar dan kebiasaan belajar. Data yang diperoleh dianalisis secara deskriptif. Berdasarkan analisis data, dapat disimpulkan bahwa mahasiswa Pendidikan biologi dapat bertanggung jawab terhadap proses pembelajaran, mempunyai keinginan untuk mencari sumber-sumber informasi baru, menerima pengalaman baru serta cara-cara baru dalam pembelajaran, mempunyai motivasi yang tinggi dan kepercayaan diri yang tinggi dalam menyelesaikan tugas dan tantangan yang diberikan oleh dosen. Meskipun demikian mahasiswa belum mempunyai kemampunan manajemen waktu yang baik karena belum secara optimal mengatur waktu belajar selama mengikuti perkuliahan secara daring.
\end{abstract}

\begin{abstract}
As a prospective biology teacher, the ability to be responsible to the learning process is indeed important to develop abilities to master biology concepts and pedagogical skills. This study aims to investigate learner autonomy in biology education program during pandemic. Survey was conducted to 61 pre-service biology teachers by using Autonomy Learning Scale (ALS) which consists of 12 questions. ALS measured two aspects, independence of learning and study habits. Independence of learning reflected responsibility for learning, openness to new experiences and inner motivation, and self- confidence, whereas study habits reflected learning practices, time management, procrastinations, and attitude to working independently. It can be concluded that pre-service biology students can be responsible for the learning process, have a desire to find new sources of information, receive new experiences and new ways of learning, have high motivation and high confidence in completing tasks and challenges, given by the lecturer. Students, however, do not have good time management skills.
\end{abstract}

Copyright (C) 2019 Universitas Negeri Medan. Artikel Open Access dibawah lisensi CC-BY-4.0 (https://creativecommons.org/licenses/by/4.0)

\section{How to Cite:}

Anazifa,R.D., Pratama, A.T., \& Limiansi, K. (2020). Learner Autonomy Mahasiswa Pendidikan Biologi Pada Pembelajaran Daring Selama Masa Pandemi. Jurnal Pelita Pendidikan, 8 (4), 206-214 


\section{PENDAHULUAN}

Kemandirian belajar menjadi salah satu tujuan pembelajaran yang ditetapkan oleh Pendidikan Tinggi. Berdasarkan rumusan sikap dan keterampilan umum dari standar nasional DIKTI (SN DIKTI) menginternalisasi semangat kemandirian adalah merukapan sikap yang wajib dimiliki oleh semua lulusan. Pada jenjang sarjana, secara lebih khusus, menunjukkan kinerja mandiri yang bermutu dan terukur merupakan salah satu keterampilan umum yang harus dimiliki. Selain itu, keterampilan lain yang harus dikuasai oleh setiap lulusan sarjana adalah mampu melakukan proses evaluasi diri terhadap kelompok kerja yang berada di bawah tanggung jawabnya, dan mampu mengelola pembelajaran secara mandiri. Menjadi manusia yang mandiri juga menjadi salah satu nilai tujuan dari institusi perguruan tinggi. Selain itu, kemandirian merupakan poin penting dari mahasiswa yang harus dikembangkan selama mereka menempuh Pendidikan Tinggi, karena kemandirian merupakan salah satu nilai tambah di dalam persaingan dunia kerja.

Teori belajar mendukung pengembangan dari kemandirian belajar. Teori humanistik memandang bahwa pembelajaran adalah cara realisasi diri. Proses pembelajaran memberikan kesempatan kepada peserta didik untuk mengambil keputusan. Pada teori ini, pembelajaran berfokus pada pengalaman dan keterlibatan pesera didik secara aktif dalam belajar. Berdasarkan teori konstruktivistik, peserta didik diberikan kebebasan untuk membangun informasi dan menciptakan makna pengetahuan secara mandiri sehingga mendorong kemandirian belajar mereka (Orakci \& Gelisli, 2017). Pembelajaran dengan teori konstruktivistik memberikan pengalaman kepada peserta didik untuk memberikan makna terhadap pengalamannya melalui proses asimilasi dan akomodasi yang bertujuan pada pembentukan struktur kognitifnya.

Pandemi Covid-19 yang terjadi di seluruh dunia mulai awal tahun 2020 hingga sekarang telah merubah sistem pendidikan tidak hanya di Indonesia tetapi di seluruh dunia. Pandemi menuntut sistem pendidikan untuk berubah dari kegiatan belajar mengajar secara tatap muka langsung menjadi online atau daring. Adanya perubahan tersebut menuntut pendidikan tinggi untuk beradaptasi dengan perubahan tersebut. Perkuliahan yang semula dilakukan di dalam kampus harus dilakukan secara online baik secara sinkronus, yaitu adanya interaksi pembelajaran antara mahasiswa dengan dosen secara real time dengan menggunakan teknologi video conference atau secara asinkronus yaitu interaksi pembelajaran dapat dilaksanakans secara fleksibel dengan mahasiswa mengakses materi yang telah dipersiapkan oleh dosen. Tidak hanya perguruan tinggi sebagai penyelenggara pendidikan yang harus beradaptasi dengan perubahan, mahasiswa juga harus mampu beradaptasi untuk belajar secara daring. Salah satu aspek belajar yang penting untuk menjamin keberhasilan peserta didik dalam mengikuti perkuliahan secara daring adalah menjadi pembelajar yang mandiri.

Learner autonomy diartikan sebagai kemampuan untuk bertanggungjawab pada kegiatan belajar yang dilaksanakan (Holec 1981). Kemampuan kemandirian dalam belajar mencakup mementukan tujuan, mendefinisikan isi dan perkembangan, memilih metode dan teknik yang digunakan, memantau prosesdur akuisisi dengan berbicara dengan benar dan mengevaluasi apa yang telah diperoleh (Little, 1991). Dickinson (1992) mendefinisikan kemandirian belajar sebagai tanggung jawab peseta didik atas keputusan yang diambil selama proses pembelajaran dan pelaksanaanya. Kemandirian belajar mencakup beberapa kemampuan diantaranya tanggung jawab atas hasil belajar, kepercayaan diri untuk mencapai tujuan dan kepercayan diri terhadap kemampuandalam menyelesaikan tugas serta menyelesaikan hambatan (self-efficacy), dan sering dihubungkan dengan self-directed learning (Chan 2001, Faezy \& Faezy, 2001, Macaskill \& Tayllor 2010; Macaskill \& Donovan, 2013). Selain itu peserta didik yang mandiri memiliki kemauan untuk berusaha memperluas pengetahuan daripada befokus pada materi yang sudah ditentukan (Thomas et al, 2015).

Penelitian menunjukkan bahwa kemandirian belajar mempunyai hubungan positif dengan kesuksesan seseorang dalam menempuh pendidikan. Hasil penelitian menunjukkan bahwa kesuksesan dalam menempuh pendidikan dapat terlihat dari kedewasaan mahasiswa dalam membaca Kembali catatan perkuliahan. 
Kemampuan tersebut menunjukkan bahwa mahasiswa mampu melaksanakan proses belajar mandiri students self- directed dan self-regulated learning (Thomas et.al. 2015). Kemandirian belajar khususnya self-efficacy, juga dikaitkan dengan presepsi mahasiswa terhadap kemampuaannya sendiri. Semakin tinggi self-efficacy, semakin tinggi kemampuan mereka untuk menjadi pembelajar yang mandiri.

Program Pendidikan Biologi telah menyusun kemandirian belajar menjadi salah satu tujuan dari embelajaran yang harus dicapai oleh setiap mahasiswa setelah mengikuti perkuliahan. Program Pendidikan Biologi yang mencetak calon guru Biologi dilatih untuk menjadi insan yang mandiri melalui serangkaian program pembelajaran, kegitan pembelajaran yang dilaksanakan selama menempuh program pendidikan membantu mahasiswa untuk mengembangkan kemandirian belajar. Self-efficacy berkembang melalui kegaitan penelitian. Kegiatan peneltian ini memberikan mahasiswa kesempatan untuk berinteraksi dan memanfaatkan literatur dan berkerja secara mandiri. Penelitian juga membantu mereka untuk mengembangkan kemampuan dalam manajemen diri. Selain itu kemandirian belajar dapat mengevaluasi sejauh mana kemampuan mereka dalam menyerap ilmu dari proses pembelajaran, khususnya melalui pembelajaran secara mandiri seperti melalui tutor sebaya.

Peneltian ini bertujuan untuk mengetahui kemandirian belajar mahasiswa Pendidikan biologi selama mengikuti perkuliahan secara daring (online) selama perkuliahan daring di masa pandemi. Pentingnya untuk mengetahui kemandirian belajar mahasiwa adalah sebagai dasar dalam penentuan pendekatan pembelajaran yang akan dirancang sehingga pembelajaran sesuai dengan kebutuhan mahasiswa yang mempunyai perbedaan karakteristik dan kebiasaan belajar.

\section{METODE PENELITIAN}

Kemandirian belajar mahasiswa Pendidikan biologi pada penelitian ini diukur dengan instrument Autonomy Learning Scale (ALS) yang terdiri dari 12 pertanyaan dengan menggunaan skala likert dengan 5 poin. Instrumen ini mengukur 2 aspek, yaitu 1) aspek kemandirian belajar dan kebiasaan dalam belajar. Aspek pertama, yaitu kemandirian belajar mencakup tanggung jawab dalam belajar, keterbukaan terhadap pengalaman baru, motivasi internal, dan kepercayaan diri. Aspek kedua yaitu kebiasaan dalam belajar mencakup perilaku dalam belajar, manajemen waktu, kebiasaan dalam menunda pekerjaan, dan perilaku untuk bekerja secara mandiri (Macaskill \& Taylor, 2010). Survei dilakukan pada 61 mahasiswa pendidikan Biologi, Fakultas Matematika dan IImu Pengetahuan Alam, Universitas Negeri Yogyakarta. Data kemandirian belajar yang dihimpun kemudian dianalisis secara deskriptif.

\section{HASIL DAN PEMBAHASAN}

Kemandirian belajar merupakan salah satu ketrampilan yang harus dikuasai pada abad 21 . Keterampilan ini mencakup kemampuan dalam menyusun tujuan baik jangka pendek maupun jangka panjang. Kemampuan dalam mengatur watu dan beban kerja secara efisien. Keterampilan ini juga mencakup kemandirian dalam memonitor, mendefinisikan, memprioritaskan, dan menyelesaikan tugas. Seseorang yang mandiri dalam belajar juga dicirikan dengan kemampuannya dalam mengesksplorasi dan memperluas materi pembelajaran dan kesempatan untuk menggali pengalaman serta mengevaluasi pengalamannya untuk kemajuan di masa depan. Selain itu komitmen dalam belajar yang dimiliki juga mencerminkan keinginan untuk selalu belajar (Trilling \& Fadel, 2010).

Aspek kemandirian belajar yang pertama adalah tanggung jawab dalam belajar. Berdasarkan hasil analisis data, sebanyak 50,8 \% mahasiswa menjawab bahwa mereka setuju dan 26,2\% menyatakan sangat setuju jika selama proses pembelajaran secara daring, mereka bertanggung jawab atas kegiatan pembelajaran yang mereka lakukan. Gambar 1 berikut ini menunjukan tanggung jawab mahasiswa dalam belajar 


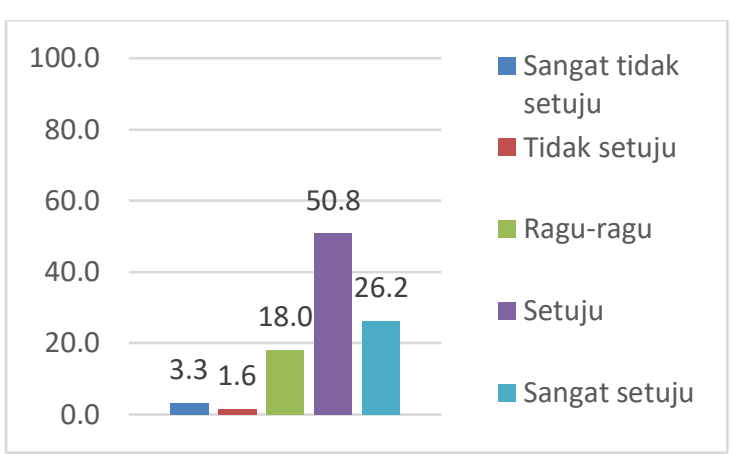

Gambar 1. Presentase tanggung jawab mahasiswa

Tanggung jawab yang dimiliki oleh mahasiswa dapat ditunjukkan dari keterilibatan secara aktif mahasiswa di kelas yang dilakukan secara daring. Untuk menciptakan tanggung jawab tersebut dibutuhkan setidaknya empat komponen, yaitu peserta didik yang mengkuti proses pembelajaran yang berlangsung, kedua keterlibatan peserta didik dalam pengalaman reflektif, ketiga adalah pengalaman belajar, dan keempat adalah keterlibagan peserta didik sebagai peribadi yang utuh (Woolfe, 1992). Chene (1983) mendefinisikan pembelajar mandiri sebagai seseorang yang mampu memperoleh pengetahuan secara mandiri, Long (1998) mendefinisikannya sebagai self-directed learning. Scott, Furnell, Murphy, \& Goulder, (2015) mendeskripsikan pembelajar mandiri sebgai kemampuan untuk memahami tujuan belajar, mengatur aspek-aspek dalam pembelajaran, dan keterlibatannya dalam proses pembelajaran.

Kegiatan pemebalajaran yang dilaksanakan secara daring juga menuntut mahasiswa untuk proaktif dalam mencari sumber-sumber belajar selain menggunakan informasi yang sudah diserikan oleh dosen. Berdasarkan hasil abalisis, 42,6\% mahasiswa setuju dan 14,8\% mahasiswa sangat setuju jika mereka menikmati mencari topik-topik yang berhubungan dengan materi perkuliahan yang sedang di bahas. Gambar 2 berikut ini menunjukkan kemauan mahasiswa dalam mencari sumber belajar baru.

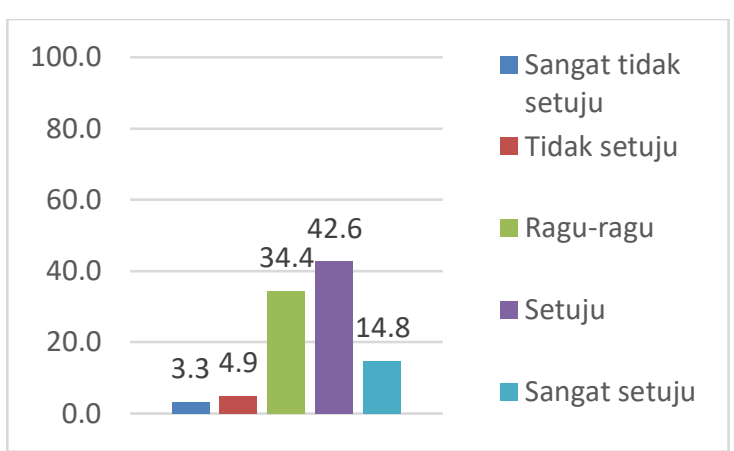

Gambar 2. Presentase kemauan mahasiswa dalam mencari informasi baru

Selama mengikuti pembelajaran secara daring, sebanyak 39,3\% mahasiswa setuju dan 27,9\% mahasiswa menjawab sangat setuju jika mereka menikmati pengalaman belajar baru yaitu adanya perubahan belajar dari tatap muka secara langsung menjadi tatap muka secara maya. Gambar 3 berikut ini menggambarkan presentase mahasiswa menikmati proses pembelajaran yang diikutinya.

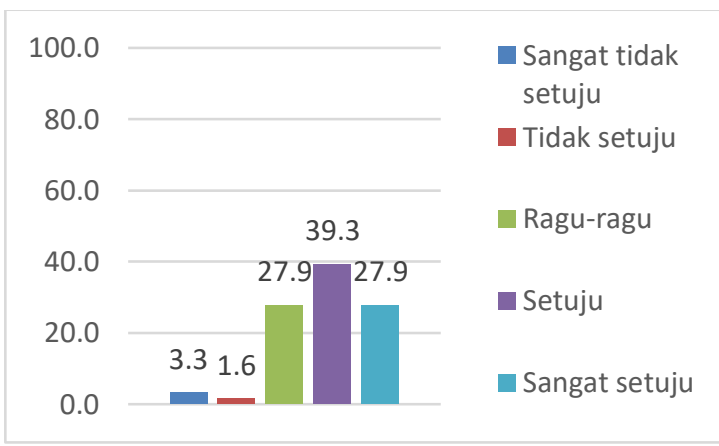

Gambar 3. Presentase mahasiswa menikmati pengalaman belajar

Pengalaman belajar baru diwujudkan dari penggunaan pratform video conference seperti Zoom, Google Meet, atau Webex untuk mengikuti perkuliahan dan penggunaan Learning Management System (LMS) selama proses perkuliahan berlangsung. Melalui LMS tersebut, mahasiswa mengikuti perkuliahan baik secara sinkronus maupun asinkronus. Mahasiswa dapat mengakses materi perkuliahan dalam bentuk handout, power point presentation, atau video. Selain itu mahasiswa juga mengerjakan tugas dan ujian serta mengumpulkannya melalui LMS tersebut. Kegiatan pembelajaran tersebut memberikan pengalaman belajar baru yang menyenangkan bagi mahasiswa. Selain keterbukaan terhadap pengalaman belajar baru, 
mahasiswa juga dapat menerima cara-cara baru dalam pembelajaran, khususnya untuk melakukan kegiatan yang sudah terbiasa mereka lakukan, misalnya pengumpulan tugas dan ujian melalui LMS. Sebanyak 45,9 \% mahasiswa menjawab setuju dan 19,7\% mahasiswa menjawab sangat setuju jika mereka terbuka terhadap cara-cara baru tersebut. Gambar 4 berikut ini menunjukkan bahwa mahasiswa terbuka terhadap cara-cara baru.

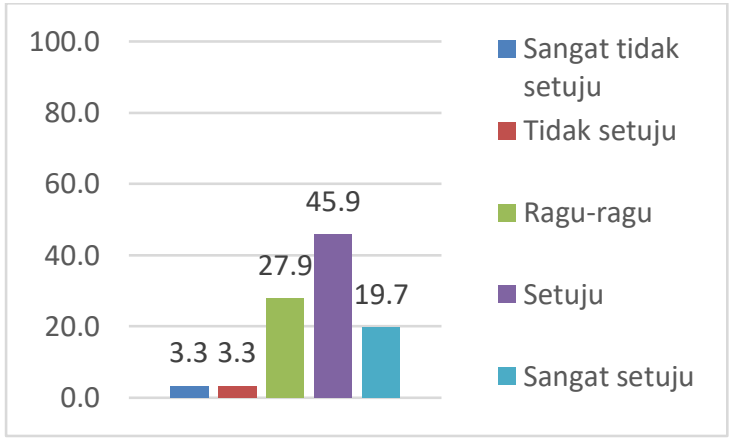

Gambar 4. Presentase mahasiswa terbuka terhadap cara-cara baru

Motivasi belajar mahasiswa berpengaruh terhadap sikap kemandirian dalam belajar. Motivasi mahasiswa selama mengikuti pembelajaran secara daring dapat ditunjukkan melalui keinginan mahasiswa dalam mengerjakan tugas sampai selesai meskipun tugas yang diberikan kepada mereka cenderung sulit. Sebanyak 42,6\% mahasiswa sangat setuju dan $36,1 \%$ setuju jika mereka akan terdorong untuk tetap menyelesaikan tugas. Gambar 5 menunjukkan kemauan mahasiswa dalam menyelesaikan tugas meskipun sulit.

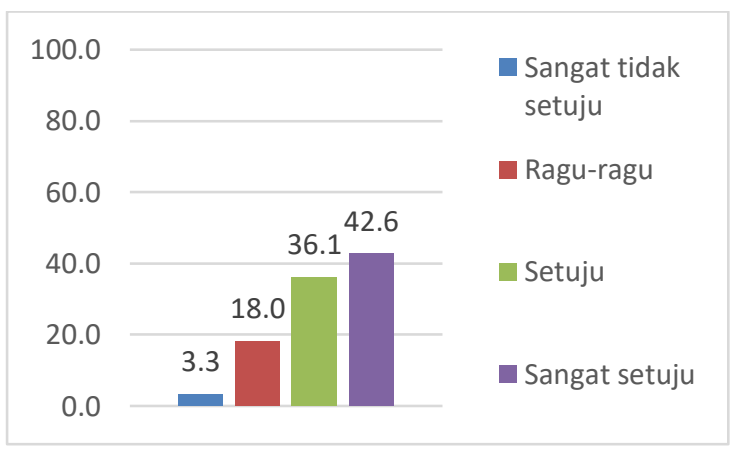

Gambar 5. Presentase kemauan mahasiswa mengerjakan tugas meskipun sulit

Hasil analisis tersebut menunjukkan bahwa motivasi sangat berpengaruh pada proses belajar
(Fitriyani, Fauzi, \& Sari; 2020). Keinginan untuk menyelesaikan tugas tersebut didorong oleh rasa keingintahuan pada mahasiswa yang tinggi, sehingga keingintahuan tersebut mendorong mahasiswa untuk menemukan apa yang ingin diketahuinya (Fauzi et al, 2017). Keinginan untuk mencapai tujuan terselesaikannya tugas ini merupakan bentuk dari motivasi internal yang muncul dari diri mahasiswa (Mediawati, 2010) Motivasi untuk menyelesaikan tugas ini juga muncul pada saat dekat dengan waktu pengumpulan tugas. Sebanyak 41\% mahasiwa cenderung terdorong untuk menyelesaikan tugas jika sudah dekat dengan batas waktu pengumpulan. Kecenderungan tersebut ditunjukan pada Gambar 6 berikut ini.

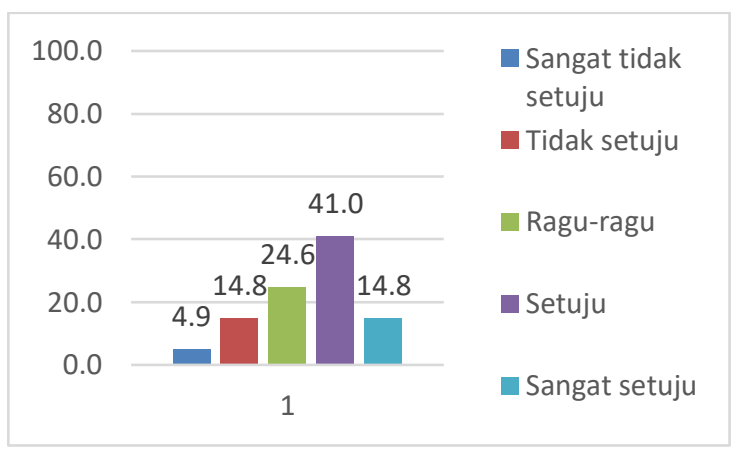

Gambar 6. Presentase motivasi mahasiswa dalam mengerjakan tugas jika sudah dekat dengan dedline

Motivasi belajar yang tinggi khusunya pada hal mengerjakan tugas yang dilakukan mahasiswa tersebut berpengaruh pada capaian belajarnya. Anas \& Aryani (2014) menyatakan bahwa mahasiswa yang melaksanakan aktifitas belajar seperti mengikuti perkuliahan, mengrhakan tugas, dan mengikuti ujian mempunyai peluang besar untuk berhasil.

Selama proses pembelajaran yang dilaksanakan secara daring, mahasiswa menikmati tantangan yang diberikan oleh dosen kepada mereka. Sikap ini menunjukkan adanya kepercayaan diri yang tinggi. Sebanyak 45\% mahasiswa setuju bahwa tantangan yang diberikan dosen kepada mereka dapat diterima. Hal tersebut dapat dilihat dari Gambar 7 berikut ini. 


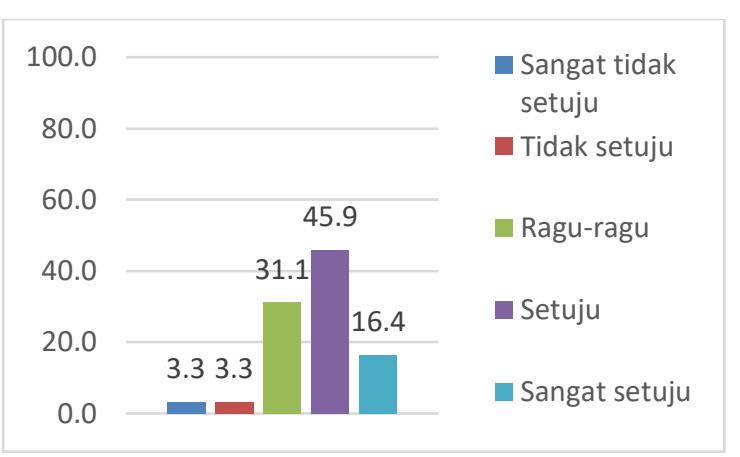

Gambar 7. Presentase mahasiswa menikmati tantangan yang diberikan oleh dosen

Kepercayaan diri tersebut merupakan bentuk sikap positif terhadap kegiatan belajar, yakni mahasiswa yakin atas kemampuannya sendiri untuk belajar dan menyelesaikan tugasnya dengan baik dan bertanggung jawab sehingga tidak mudah terpengaruh oleh orang lain. Kepercayaan diri ini juga berhubungan dengan motivasi. Seseorang yang mempunyai motivasi tinggi selalu ingin memenuhi keinginan yang muncul dan mempunyai keterampilan dalam mengatasi permasalahan yang dihadapi. Tingkat kepercayaan diri yang dimiliki mahasiswa mempengaruhi kemampuan belajar mandiri pada mahasiswa dan berpengaruh pada pengembagan diri mahasiswa. Mahasiswa yang tidak mempunyai rasa percaya diri akan sulit untuk mengembangkan kemampuanya (Rochimah \& Suryadi, 2018).

Pembelajaran daring yang diikuti oleh mahasiswa juga melatih mahasiswa untuk dapat mengorganisasi waktu belajar. Mahasiswa mempunyai otoritas diri dalam mengatur waktu untuk memahami materi perkuliahan secara lebih leluasa. Berdasarkan hasil analisis, sebanyak 47,5\% mahasiwa menyatakan bahwa mereka ragu-ragu jika mereka mampu merencanakan waktu belajar dengan baik, sedangkan 36,1\% lainnya setuju jika mereka dapat merencanakan waktu belajarnya. Hal tersebut digambarkan pada Gambar 8 berikut ini.

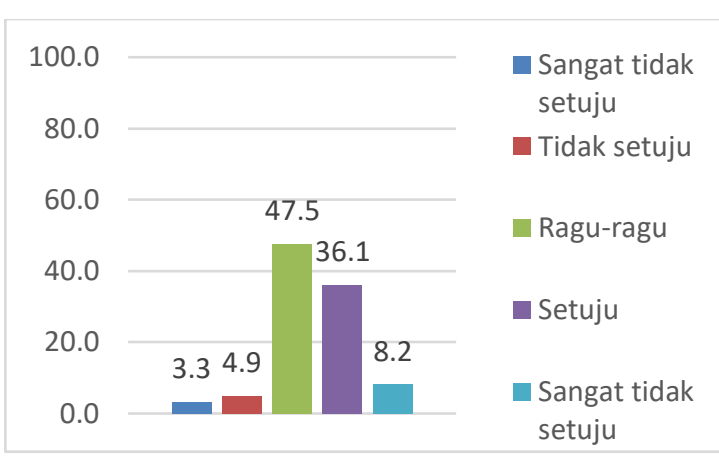

Gambar 8. Presentase mahasiswa dapat merencanakan waktu belajar

Meskipun demikian mahasiswa belum dapat mengatur waktu belajar dengan baik. Berdasarkan analisis data, 49,2\% dari mahasiswa ragu-ragu jika mereka mampu mengatur waktu belajar mereka dengan efektif. Kemampuan untuk mengatur waktu belajar berhubungan dengan management diri. Manajemen waktu ini memberikan kontribusi kepada seseorang untuk bekerja secara efektif, sehingga berpengaruh pada kesuskesan akademik (Kwan \& Ko, 2002). Gambar 9 berikut menunjukkan kemampuan mahasiswa dalam mengatur waktu.

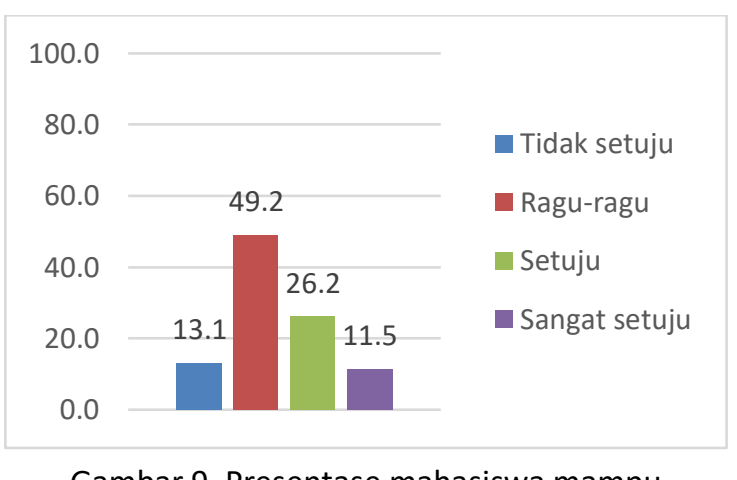

Gambar 9. Presentase mahasiswa mampu mengatur waktu

Kemampuan mahasiswa untuk mengorganisasi waktu belajar yang cukup baik dapat disebabkan karena selama proses pembelajaran secara daring mahasiswa masih sering menunda dalam mengerjakan pekerjaan misalnya tugas. $26 \%$ mahasiswa setuju jika mereka masih menunda pekerjaan dan sebanyak 47,5\% mahasiswa ragu-ragu jika mereka menunda pekerjaan mereka. Hal tersebut tergambar dalam Gambar 10 berikut ini. 


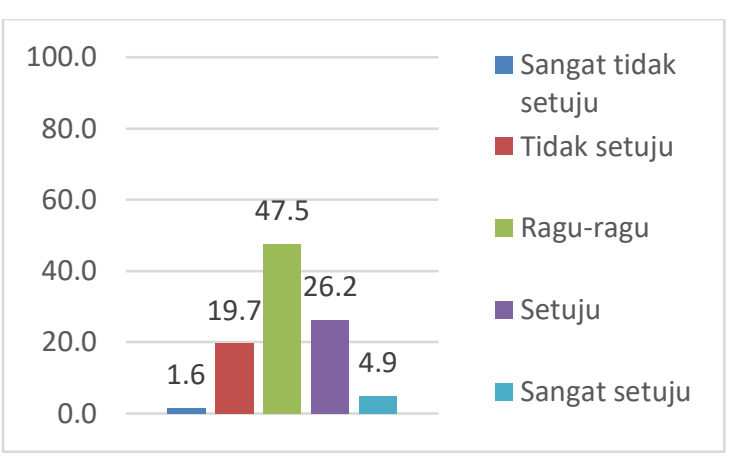

Gambar 10. Presentase mahasiswa menunda menyelesaikan pekerjaan

Meskipun demikian, jika dikaitkan dengan kebiasaan mereka dalam menunda pekerjaan dan kemapuannya menghadapi deadline, sebanyak 47,5\% mahasiswa setuju bahwa mereka dapat menghadapi deadline dengan baik seperti yang tergambar pada Gambar 11 berikut ini.

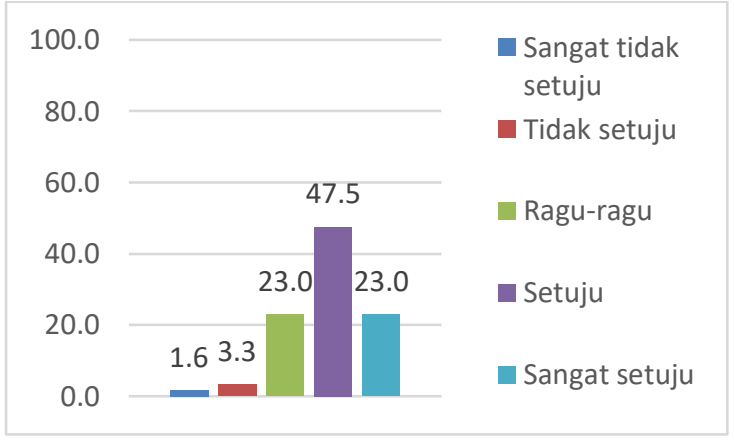

Gambar 11. Presentase kemampuan mahasiswa mengadapi deadline

Kurang optimalnya pengorganisasian pada mahasiswa ini berhubungan dengan kemampuan individu untuk melakukan management diri, khusunya waktu. Hal ini berhubungan dengan kemampuan individu untuk menyusun skala prioritas. Akibatnya adalah banyak waktu yang terbuang dan pekerjaan akan menumpuk mendekati waktu pengumpulan tugas.

Adanya keterbatasan untuk berinteraksi secara langsung dengan teman satu kelas dan dosen pengampu mata kuliah, mahasiwa cenderung dapat bekerja secara mandiri. Sebanyak 42,6\% mahasiwa setuju bahwa selama belajar secara daring, mereka suka untuk bekerja sendiri, misalnya baik untuk mempelajari materi kuliah yang telah disediakan oleh dosen maupun untuk mengerjakan tugas. Hal tersebut tergambar pada Gambar 12 berikut ini.

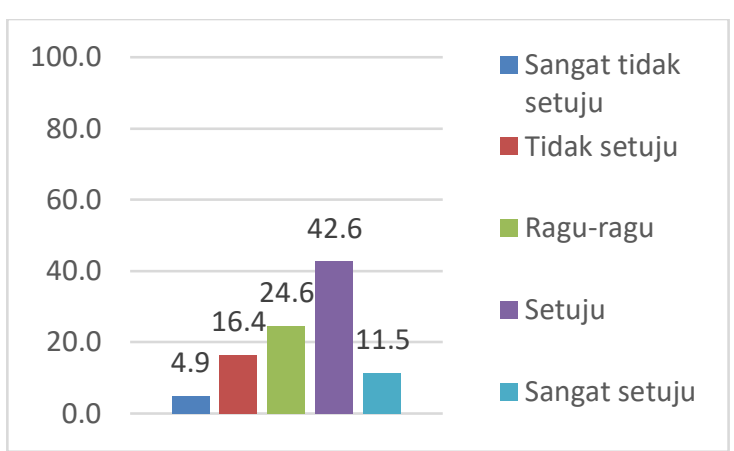

Gambar 12. Presentase mahasiswa suka bekerja sendiri

Berdasarkan teori self-regulated learning (Zimmerman, 1989), kemampuan mahasiswa untuk bekerja secara mandiri menunjukkan bahwa mereka mempunyai kesadaran diri atas potensi yang dimiliki dan dapat menggunakannyaa dengan baik dalam proses pengaturan diri terhadap proses pembelajaran yang berlangsung.

Kemandirian yang dimiliki mahasiswa Pendidikan biologi dapat dikembangkan melalui serangkaian program pembelajaran, yaitu melalui perkuliahan dan praktikum. Kegiatan pembelajaran yang dilaksanakan berpusat pada mahasiswa. Kemandirian belajar dapat dikembangkan melalui pembelajaran yang berpusat pada peserta didik. Jalil, Sbeih, Boujettif (2009) menyatakan bahwa pembelajaran yang berpusat pada peserta didik (student- centered learning approach) dapat meningkatkan perilaku positif pada pembelajaran sains, meningkatkan ketercapaian pembelajaran, dan membangun kepercayaan diri terhadap kemampuan diri untuk belajar sains secara mandiri. Mengembangkan kemampuan mahasiswa sebagai pembelajar mandiri dapat dilakkan dengan memfasilitasi mereka untuk mengembangkan kemandiriannya melalui program-program khusus untuk meningkatkan self-efficacy dan self-esteem mahasiwa (Macaskill \& Donovan, 2013). Selain itu, pembelajaran mandiri juga merupakan elemen penting dalam menciptkan pembelajaran yang berkualitas (Rochimah \& Suryadi, 2018).

\section{KESIMPULAN}

Berdasarkan hasil penelitian, mahasiswa Pendidikan Biologi dapat mengimplementasikan aspek-aspek pembelajar mandiri secara baik pada aspek tanggung jawab terhadap proses pembelajaran, keinginan untuk mencari sumber- 
sumber informasi baru, menerima pengalaman baru serta cara-cara baru dalam pembelajaran. Mahasiswa juga mempunyai motivasi yang tinggi dalam menyelesaikan tugas dan tantangan yang diberikan oleh dosen. Selama proses pembelajaran daring berlangsung mahasiswa mempunyai kepercayaan diri yang tinggi. Meskipun demikian mahasiswa Pendidikan biologi belum mempunyai kemampunan manajemen waktu yang baik karena belum secara optimal mampu mengatur waktu belajar selama mengikuti perkuliahan jarak jauh.

\section{DAFTAR PUSTAKA}

Anas, M., \& Farida Aryani. (2014). Motivasi Belajar Mahasiswa. Jurnal Peneltian Pendidikan INSANI. 16(1). 41-46.

Chan, V. (2001). Readiness for learner autonomy: what do our learners tell us? Teaching in Higher Education, 6(4), 505-518.

Chene, A. (1983). The concept of autonomy in adult education: A philosophical discussion. Adult Education Quarterly. 34(1). 38-47.

Dickinson, L. (1992). Learning Autonomy 2: Learner training for language learning. Dublin: Authentik.

Fazey, D.M., and J.A. Fazey. (2001). The potential for autonomy in learning: Perceptions of competence, motivation and locus of control in first-year undergraduate students. Studies in Higher Education. 26(3). 345-61.

Fauzi, A. R., Zainuddin, \& Atok, R. Al. (2017). Penguatan Karakter Rasa Ingin Tahu dan Peduli Sosial melalui Discovery Learning. Jurnal Teori Dan Praksis Pembelajaran IPS. 2(2). 27-36.

Fitriyani, Y., Fauzi, I., \& Sari, M. (2020). Motivasi Belajar Mahasiswa Pada Pembelajaran Daring Selama Pandemik Covid-19. Jurnal Kependidikan: Jurnal Hasil Penelitian dan Kajian Kepustakaan di Bidang Pendidikan, Pengajaran dan Pembelajaran. 6(2).

Holec, H. 1981. Autonomy in foreign language learning. Oxford: Oxford University Press.

Jalil, Pasl A, M. Z. Abu Sbeih, M. Boujettif and R. Barakat. (2009). Autonomy in Science Education: A Practical Approach in Attitude Shifting Towards Science Learning. Journal of Science Education and Technology. 18(6), 476-486.
Kwan, A. S. F., \& Ko, E. I. (2002). More on Helping University Students To Manage Their Time Better. Hong Kong: City University of Hongkong.

Little, D. (1991). Learner Autonomy: Definitions, issues and problems. Dublin: Authentic Limited.

Long, H.B. (1998). Theoretical and practical implications of selected paradigms of selfdirected learning. In Developing paradigms for self-directed learning, ed. H.B. Long \& Associates, 1-14. Norman, OK: Public Managers Centre, College of Education, University of Oklahoma.

Macaskill, A., \& Denovan, A. (2013). Developing autonomous learning in first year university students using perspectives from positive psychology. Studies in Higher Education. 38 (1). 124-142.

Macaskill, A. \& Taylor, E. (2010). The Development of a Brief Measure of Learner Autonomy in University Students. Studies in Higher Education. 35(3). 351-359.

Mediawati, Elis. (2010). Pengaruh Motivasi Belajar Mahasiswa Dan Kompetensi Dosen Terhadap Prestasi Belajar. Jurnal Pendidikan Ekonomi Dinamika Pendidikan. 5(2). 134-146.

Orakci, Senol \& Yucel Gelisli. (2017). Learner Autonomu Scale: A Scale Development Study. Malaysian Onine Joirnal of Educational Sciences. 5(4).25-35.

Rochimah, N., Suryadi. (2018). Pengaruh Motivasi Berprestasi Dan Kepercayaan Diri Terhadap Belajar Mandiri Mahasiswa. El-Banar: Jurnal Pendidikan dan Pengajaran. 1(1).

Santyasa, I.W. (2013). Pembelajaran Sains Inovatif: Strategi Self-Regulated Learning sebagai Fasilitas Belajar Alternatif dalam Rangka Menjawab Tantangan Abad Ke-21. Makalah disajikan dalam Seminar Nasional Pendidikan Sainsi di Universitas Negeri Yogyakarta.

Scott, G.W., J. Furnell, C.M. Murphy \& R. Goulder (2015) Teacher and student perceptions of the development of learner autonomy; a case study in the biological sciences. Studies in Higher Education. 40:6, 945-956.

Trilling, B. \& Fadel, C. (2010). 21 $1^{\text {st }}$ Century Sills: learning for Life in Our Times. San Fransisco: Jossey-Bass A Wiley Imprint.

Woolfe, R. (1992). Experiential learning in workshops. In Hobbs, T. (ed.) 1992. 
Experiential training: practical guidelines.

London: Tavistock/ Roudledge, 1- 13.

Zimmerman, B.J. (1989). A Social Cognitive View of

Self-Regulated Academic Learning. Journal

of Educational Psychology. 81. 0022-0663. 